\title{
Aspergillus spp. isolates from bovine rumen can increase the digestibility and degradability of forages
}

Isololados de Aspergillus spp. provenientes do rumen podem melhorar a digestibilidade e degradabilidade de forrragens

Aislamientos de Aspergillus spp. del rumen puede mejorar la digestibilidad y degradabilidad del forrajes

Flavia Oliveira Abrão

ORCID: https://orcid.org/0000-0002-9768-7405 Instituto Federal de Educação, Ciência e Tecnologia Goiano, Brazil E-mail:flavia.abrao@ifgoiano.edu.br

Eduardo Robson Duarte

ORCID: https://orcid.org/0000-0002-2205-9412

Universidade Federal de Minas Gerais, Brazil

E-mail:duartevet@hotmail.com

Moisés Sena Pessoa

ORCID: https://orcid.org/0000-0002-2168-4099 Instituto Federal de Educação, Ciência e Tecnologia Goiano, Brazil E-mail: moisessena@yahoo.com.br

Otaviano de Souza Pires Neto

ORCID: https://orcid.org/0000-0002-1159-4559 Faculdades Integradas do Norte de Minas, Brazil

E-mail: opiresneto@gmail.com

Anna Carolynne Alvim Duque ORCID: https://orcid.org/0000-0003-3552-4173

Universidade Federal de Minas Gerais, Brazil E-mail: alvimduque@gmail.com

Vera Lúcia dos Santos

ORCID: https://orcid.org/0000-0001-5815-5652

Universidade Federal de Minas Gerais, Brazil

E-mail: verabio@gmail.com

Luciana Castro Geraseev

ORCID: https://orcid.org/0000-0001-8926-0367

Universidade Federal de Minas Gerais, Brazil

E-mail: lgeraseev@gmail.com

Eloísa de Oliveira Simões Saliba

ORCID: https://orcid.org/0000-0003-4607-8404

Universidade Federal de Minas Gerais, Brazil

E-mail: eloiza@ufmg.br

Norberto Mario Rodriguez:*:

ORCID: https://orcid.org/0000-0003-1960-9943

Universidade Federal de Minas Gerais, Brazil

E-mail: norberto.bhe@terra.com.br

In Memoriam

\begin{abstract}
The bovine production on pastures is a sustainable activity, responsible to generating income and employments in many tropical regions. However, in this system a major obstacle occurs during long dry periods, when the forages show low nutritional quality. In this research we evaluated the in vitro digestibility and degradability of Urochloa decumbens and Cynodon dactylons var Tiffton 85 inoculated with isolates of Aspergillus spp. from the gastrointestinal tract cattle. Four cows with rumen fistula were used as rumen contents donors to determine the in vitro digestibility of dry matter (IVDMD). The treatments were, as follows: control - No fungal inoculum, AT13 - (with Aspergillus terreus isolate), AF69 - (with Asperillus fumigates isolate, MIX (with mix of fungi AT13 and AF69). The analyses were performed in rumen simulator with four replications. The gas production was determined by semiautomatic method for both gas and the mechanics ability to fiber colonization of these fungi isolates were evaluated by scanning electron microscopy. The inclusion of AF69 and MIX promoted significant increase of IVDMD of $U$. decumbens $(41.4-42.1 \%)$. The dry matter degradability were not influenced by the inoculums types using the by
\end{abstract}


semi-automatic gas production method However, they linearly increased with fermentation time. The two isolates of Aspergillus spp. were able to colonize the $U$. decumbens fiber showing production of mycelium and reproductive structures in electronic microscopic analyses. The addition these Aspergillus isolates promotes significant increase of IVDMD to $U$. decumbens, indicating promising potential for development of microbial or probiotic additive to cattle raised on lignified tropical pasture.

Keywords: Cattle; Ruminant nutrition; Fungi of rumen; Tropical pasture; Fungi colonization.

\title{
Resumo
}

A produção bovina em pastagem é uma atividade sustentável, responsável por gerar renda e empregos em diversas regiões tropicais. No entanto, neste sistema, um entrave $\theta$ ocorre durante os longos períodos de seca, quando as pastagens apresentam baixa qualidade nutricional. Nesta pesquisa os objetivos foram avaliar a digestibilidade e degradabilidade in vitro de Urochloa decumbens e Cynodon dactylons var Tiffton 85 inoculados com isolados de Aspergillus spp. do trato gastrointestinal bovino. Quatro vacas com fístula ruminal foram utilizadas como doadoras de conteúdo ruminal para determinar a digestibilidade in vitro da matéria seca (IVDMD). Os tratamentos foram os seguintes: Controle- Sem inóculo fúngico (controle), AT13 - (com isolado Aspergillus terreus) , AF69 - (com isolado Asperillus fumigatus), MIX (com mix dos fungos AT13 e AF69). As análises foram realizadas em simulador ruminal com quatro repetições. A produção de gás foi determinada por método semi-automático para ácidos graxos do rumen e a capacidade mecânica de colonização das fibras vegetais por esses fungos foi avaliada por microscopia eletrônica de varredura. A inclusão de fungos of AF69 and MIX promoveram aumento significativo de IVDMD de $U$. decumbens $(41,4-42,1 \%)$. As degradabilidades da matéria seca não foram influenciadas pelos tipos de inoculantes, quando se utilizou o método de produção de gás semiautomático; entretanto, aumentaram linearmente em função do tempo de fermentação. Os dois isolados de Aspergillus spp. foram capazes de colonizar fibras de U. decumbens, mostrando produção de micélio e estruturas reprodutivas em análises de microscopia eletrônica. A adição desses isolados de fungos selecionados promove aumento significativo de IVDMD para $U$. decumbens, indicando potencial promissor para o desenvolvimento sustentável de aditivo microbiano ou probiótico para bovinos criados em pastagem tropical lignificada.

Palavras-chave: Bovinos; Nutrição de ruminantes; Fungos do rúmen; Pastagem tropical; Colonização por fungos.

\begin{abstract}
Resumen
La ganadería de pastoreo es una actividad sustentable, responsable por generar ingresos y empleos en varias regiones tropicales. Sin embargo, en este sistema, un obstáculo se presenta durante los largos períodos de sequía, cuando los pastos tienen baja calidad nutricional. En esta investigación, la digestibilidad y degradabilidad in vitro de Urochloa decumbens y Cynodon dactylons var Tiffton 85 inoculados con Aspergillus spp. del tracto gastrointestinal bovino. Se utilizaron cuatro vacas con fístula ruminal como donantes de contenido ruminal para determinar la digestibilidad in vitro de materia seca (IVDMD). Los tratamientos fueron los siguientes: control- Sin inoculo de hongos, AT13 - (con aislado Aspergillus terreus), AF69 - (con aislado Aspergillus fumigatus), MIX (con mezcla de hongos AT13 y AF69). Los análisis se realizaron en un simulador ruminal con cuatro repeticiones. La producción de gas se determinó mediante un método semiautomático para los ácidos grasos del rumen y la capacidad mecánica para la colonización de las fibras vegetales por estos hongos se evaluó mediante microscopía electrónica de barrido. La inclusión de hongos AF69 y MIX promovió aumento significativo de IVDMD de U. decumbens (41,4 - 42,1\%). Los tipos de inculon no influyeron en la degradabilidad de la materia seca cuando se utilizó el método de producción de gas semiautomático. Sin embargo, aumentaron linealmente con el tiempo de fermentación. Los hungos pudieron colonizar fibras de $U$. decumbens, mostrando producción de micelio y estructuras reproductivas. La adición de estos aislados de hongos seleccionados promueve un aumento significativo de IVDMD para $U$. decumbens, lo que indica un potencial prometedor para el desarrollo sostenible de aditivo microbiano o probiótico para el ganado criado en pastos tropicales lignificados.
\end{abstract}

Palabras clave: Bovinos; Nutrición de rumiantes; Hongos del rumen; Pastos tropicales; Colonización por hongos.

\section{Introduction}

The remarkable capacity of protein production in ruminants is attributed to the pre-stomach system which houses a complex microbial ecosystem (Kamra, 2005; Liu et al. 2020; Russell and Rychlik 2001). However, in semiarid tropical regions, the quantity of available fodder and the pasture quality are compromised during dry periods when the physiological lignification of the vegetal cell wall reduces the forage digestibility (Moore, and Jung 2001).

Alternatively, fungus species produce synergistically-acting lignocellulolytic enzymes which reduce lignocellulosic residues in nature and to favor the cellulose releasing and other carbohydrates for ruminant feed (Dashtban et al. 2001; Russell and Rychlik 20002001). 
Anaerobic ruminal fungi shows major importance for tropical forage digestion and degradation lignified fibers (Hartinger et al. 2021; Paul et al. 2004). However theses fungi have showed labors culture conditions in laboratory (Hartinger et al. 2021). Alternatively, facultative anaerobic fungi have notable production of enzymes that facilitate polysaccharide degradation in ruminants. Microbial cultures of Aspergillus oryzae, and the extracts of these fungi may been used as supplements in ruminant diets, improving productivity by 7-8\% (Chiou et at., 2002; Sobhy Sallam et al. 2020).

In an earlier study, beef cattle feeding only on lignified tropical pastures contained predominantly Aspergillus spp. in the rumen fluid between fungi isolates (Abrão et al. 2014). Isolates of this genus has shown potential for supplementation of animal feeds as well as for industrial purposes (Facchini et al. 2012, Sallam Sobhy et al. 2020; Zilio et al. 2019). Aspergillus spp. isolates from the digestive tract of dairy cattle expressed notable capacity for microcrystalline cellulose degradation and were not micotoxin producer of (Almeida et al. 20172014; Abrão et al. 2018). The inclusion of additives containing exogenous fungi and their enzymes to ruminant diets has promoted increase of ruminant production by optimizing digestion (Yang et al. 2000).

We previously selected two isolates of Aspergillus spp. presenting probiotic characteristics and superior ability to degrade vegetal cell wall (Abrão et al. 2017; Abrão et al. 2018). Here we are evaluating the hypothesis that these fungi, isolated from bovine digestive tract, could colonize lignified grass fibers and to improve their digestibility and dry matter degradability when inoculated in a ruminal simulation environment.

\section{Methodology}

\subsection{Fungal isolates}

We evaluated an isolated of Aspergillus terreus (AT13), Acc. Genbank KF781532, from the rumen and one isolate of Aspergillus fumigatus (AF69), Acc. Genbank KF781534,- from the rectum of Nellore calves raised in U. decumbens in the north of Minas Gerais, Brazil, during the dry season (Abrão et al. 2014). These isolates were identified after the amplificaction of ITS region of rDNA and the sequencing was performed with DYEnamic (Amersham Biosciences, USA) in a Mega-BACE 1000 automated sequencing system at the Genome Analysis Center and Gene ExpressionThe obtained DNA sequences were analyzed using BLASTn (v.2.215) of BLAST 2.0 at the NCBI website, as reported by (Abrão et al. 2017).

In previous studies, these isolates showed superior production of degradation enzymes of plant cell wall, tolerance to ruminal fermentation fatty acids, did not produce mycotoxins and increased the production of gluconic, butyric and acetic acids in the fermentation of $U$. decumens (Abrão et al. 2017, Abrão et al. 2018)

\subsection{Evaluated forages}

Samples of Urochloa decumbens hay were collected during the dry period in the North of Minas Gerais, a semiarid tropical region. Tifton 85 (Cynodon dactylons) hay was commercially purchased in the region of Belo Horizonte - MG, Brazil. Analyzes were performed to determine the dry matter (DM), Ashes; Neutral detergent fiber (NDF); Acid detergent fiber (ADF); Crude protein (CP); Soluble protein; Ethereal extract (EE); Lignin; Calcium (Ca); Phosphorus (P); Potassium (K); Magnesium (Mg); Sulfur (S); Sugars (carbohydrates soluble in ethanol); Neutral detergent insoluble protein (PIDN); Acid detergent insoluble protein (PIDA); Digestibility of the standardized NDF for 24, 30 and 48 hours (Combs Method - Goeser); kd of NDF and non-soluble carbohydrates (NSC) (Near Infrared Spectroscopy - NIRS) (Table 1). The study was performed in Belo Horizonte city, Minas Gerais, Brazil (Latitude: -19.8157 South, Longitude: -43.9542 West) and altitude 767m. 
Table 1 -Nutricional composition Urochloa decumbens and Cynodon dactylons var Tifton 85 and sampled during the dry season.

\begin{tabular}{|c|c|c|}
\hline Composition & U. decumbens & C. dactylons var Tifton 85 \\
\hline Dry matter $(\%)$ & 93.05 & 93.30 \\
\hline Crude protein $(\% \mathrm{DM})$ & 4.63 & 9.60 \\
\hline Soluble protein (\%CP) & 11.31 & 45.87 \\
\hline PIDN (\%CP) & 25.92 & 16.56 \\
\hline PIDA (\%CP) & 14.04 & 6.67 \\
\hline NDF (\%DM) & 77.74 & 62.51 \\
\hline $\mathrm{ADF}(\% \mathrm{DM})$ & 51.40 & 40.15 \\
\hline Lignin (\%DM) & 7.88 & 5.16 \\
\hline Sugars (\%DM) & 3.27 & 7.74 \\
\hline $\mathrm{EE}(\% \mathrm{DM})$ & 1.35 & 1.87 \\
\hline Ashes (\%DM) & 5.91 & 6.86 \\
\hline $\mathrm{Ca}(\% \mathrm{DM})$ & 0.15 & 0.42 \\
\hline $\mathrm{P}(\% \mathrm{DM})$ & 0.11 & 0.21 \\
\hline $\mathrm{K}(\% \mathrm{DM})$ & 0.51 & 1.65 \\
\hline $\operatorname{Mg}(\% \mathrm{DM})$ & 0.13 & 0.22 \\
\hline $\mathrm{S}(\% \mathrm{DM})$ & 0.07 & 0.11 \\
\hline Digestibility of NDF- $24 \mathrm{~h}$ & 10.21 & 32.2 \\
\hline Digestibility of NDF- $30 \mathrm{~h}$ & 22.94 & 40.99 \\
\hline Digestibility of NDF- $48 \mathrm{~h}$ & 31.67 & 55.82 \\
\hline $\mathrm{Kd}$ of $\mathrm{NDF}$ & 2.82 & 4.74 \\
\hline NSC & 11.57 & 20.75 \\
\hline
\end{tabular}

Note: Dry matter (DM), Neutral detergent fiber (NDF); Acid detergent fiber (ADF); Crude protein (CP); Soluble protein; Ethereal extract (EE); Calcium (Ca); Phosphorus (P); Potassium (K); Magnesium (Mg); Sulfur (S); Neutral detergent insoluble protein (PIDN); Acid detergent insoluble protein (PIDA); Digestibility of the standardized NDF for 24, 30 and 48 hours; non-soluble carbohydrates (NSC). Source: Authors.

\subsection{In vitro digestibility of dry matter of forages}

The fungi were cultured in microaerophilia, in Sabouraud broth at $39^{\circ} \mathrm{C}$ under shaking for $48 \mathrm{~h}$ and were standardized to approximately $10^{8}$ spores/ $\mathrm{mL}$. Four cows with ruminal fistulas were used to ruminal fluid donors. These animals were housed in individual stalls for 15 days, with 14 days for adaptation to diets $(70 \%$ Tifton 85 hay $+30 \%$ commercial concentrate + mineral mix) and on the last day the ruminal fluid was collected. The ruminal contents were homogenized, filtered and stored in thermal bottles and immediately sent for analysis. All the procedures were approved by the Animal Experimentation Ethics Committee of the Federal University of Minas Gerais under registration CETEA 128/2013.

In vitro dry matter digestibility coefficients (IVDMD) of $U$. decumbens and Tifton 85 hay (Cynodon spp.) were evaluated according to the methodology described by Tilley and Terry (1963), following the modifications described by Holden (1999) with the use of the rumen simulator (DaisyII Ankon®). This apparatus consists of four jars for anaerobic incubation at $39^{\circ} \mathrm{C}$ and constant rotation. Each jar received a treatment, being Control - Without fungal inoculum ( only $20 \mathrm{~mL}$ 
of Sabouraud broth medium), AT13- With Aspergillus terreus (20 mL inoculum), AF69 - With Aspergillus fumigatus (20 mL inoculum), AT13 and AF69 - With mix of both fungi (10 mL inoculum of each fungus).

The bulks were mill milled with a $1 \mathrm{~mm}$ sieve and $0.25 \mathrm{~g}$ samples were packed in Ankon® F-57 sachets with 57 micron porosity. Six replicates and four repetitions were performed and the samples remained in contact with each treatment and ruminal fluid plus McDougall's buffer solution for 48 hours (1: 3 ratio). Subsequently, pepsin and hydrochloric acid were added to simulate the chemical digestion, remaining in contact for another 24 hours. At the end of this process the sachets were washed, dried and weighed. The determination of the IVDMD was obtained by the formula Ankom (2014).

$\% \operatorname{IVDMD}(\mathrm{DM}$ base $)=100-(\mathrm{W} 3-(\mathrm{W} 1 \times \mathrm{C} 1)) /(\mathrm{W} 2 \times \mathrm{DM}) \times 100$.

Where:

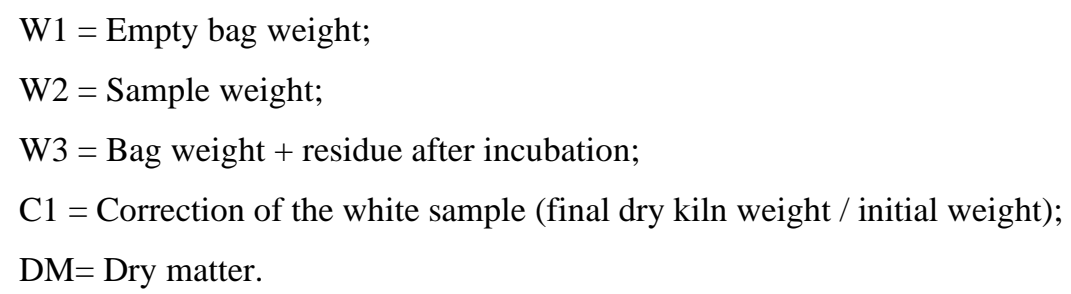

The statistical design used in this study was in a randomized block in factorial $4 \times 2$ (fungi $x$ forage source) with four repetitions. Each block was a period of evaluation. Normality and homoscedasticity of variances were evaluated using the Lilliefors and Bartlett tests, respectively. The data were submitted to analysis of variance using the ASSISTAT 7.7 Beta statistical program and the means compared by the Scott-Knott test at the $5 \%$ probability level $(P \leq 0.05)$.

\subsection{Evaluation of the degradation and fermentation of the fodders by the semi-automatic gas production method}

The inoculations with saline containing the fungus AT13, the AF69 or MIX of both fungi were evaluated. Saline solution without fungal spores was used in the control. Samples of $U$. decumbens and Tifton 85 hay were ground in a $1 \mathrm{~mm}$ sieve mill and incubated in glass vials of $160 \mathrm{~mL}$ capacity, prewashed with distilled water and dried. Subsequently the vials were saturated with carbon dioxide (Ankom 2014).

Two flasks (replicates) were used per sample of roughage by gas production time (subplot) incubated with pooled rumen liquid from cows fed as previously described. An Ankom sac was filled with approximately $0.5 \mathrm{~g}$ of the bean per fermentation flask along with $12.5 \mathrm{~mL}$ of buffer culture medium and $4 \mathrm{~mL}$ of the ruminal fluid with $0.5 \mathrm{~mL}$ of standardized microbial additive $\left(10^{8}\right.$ spores $\left./ \mathrm{mL}\right)$. In the control the same procedure was adopted replacing the fungal additives with sterile saline solution. To eliminate the residual effect of the sachets, blank bottles containing the empty sachets were evaluated in duplicate for each treatment and control (Ankom 2014).

After inoculation, the flasks were kept in an oven at $39^{\circ} \mathrm{C}$ and gas production was measured at 2, 4, 6, 8, 10, 12, 15, $18,21,24,30,36,48,60,72$ and 96 hours of incubation using a pressure transducer connected to a needle ( $25 \mathrm{~mm} \times 7 \mathrm{~mm})$. The dry matter degradability was obtained by the difference between the initial dry weight of the sample bags and the residue obtained at the times of $6,12,24,48,96 \mathrm{~h}$. The sachets were then kept for $8 \mathrm{~h}$ in a $105^{\circ} \mathrm{C}$ oven, after which they were weighed and the weight used to calculate the DM degradability (Ankom 2014).

The pressure data (psi) were used to calculate the volume of gases $(\mathrm{mL})$ produced according to the mathematical equation standardization for tropical forages: $\mathrm{mL}=-0.085+3.582 \mathrm{psi}+0.019 \mathrm{psi}^{2}$. Subsequently, the accumulated gas productions $(\mathrm{mL})$ were estimated. 
Normality and homoscedasticity of variances were evaluated using the Lilliefors and Bartlett tests, respectively. In order to evaluate the degradability of the dry matter and gas production of the two bulks, the design was used in randomized blocks with subdivided plots. In the plots the effects of the inclusion of the fungi and the blocks were studied, while in the subplots. The effects of the incubation time and its interaction with the treatments tested (4 treatments $\times 16$ times x 2 blocks). The means were compared by the Scott-Knott test $(P<0.05)$. As the quantitative factor "time" was significant, regression analysis was applied to the degradability variable. The ASSISTAT 7.7 Beta software was used for data analysis. The cumulative gas production was presented in a descriptive way.

\subsection{Scanning electron microscopy analysis}

For inoculation of evaluated fungi isolates, spore suspensions were obtained from colonies cultured for seven days in Cellulose medium at $37{ }^{\circ} \mathrm{C}$. Ten $\mathrm{mL}$ of a suspension was prepared in saline plus $0.1 \%$ Tween $20 \AA(\mathrm{v} / \mathrm{v})$, containing $10^{8}$ spores $/ \mathrm{mL}$.

Fragments of $U$. decumbens were obtained from rectangular cuts of approximately $2 \mathrm{~cm}$. In duplicate, the forage was wrapped in sterile petri dishes and each replicate received $50 \mu \mathrm{L}$ of the fungal solution described above. The control consisted only of fragments of the bulk without addition of microorganisDM and $50 \mu \mathrm{L}$ of sterile saline solution.

For scanning electron microscopy (SEM) analyzes, samples were obtained at times 0,24 and $96 \mathrm{~h}$ after inoculation. The plant fragments were fixed in $2 \%$ paraformaldehyde solution, $2 \%$ glutaraldehyde in buffer $(0.1 \mathrm{M}$ potassium cacodylate, $\mathrm{pH}$ 7.2), kept under refrigeration $\left(4{ }^{\circ} \mathrm{C}\right)$ overnight and were analyzed by means of scanning electron micrographs (Subsequently, washing ( $3 \times 15 \mathrm{~min})$ in the same buffer was dehydrated after successive ethanol treatments (30\%, 50\%, 70\%, 90\%, 100\%, - 15 min each) and subsequently dehydrated in critical point apparatus $\left(\mathrm{CO}_{2}\right)$ (Autosamdriß, 815, Series A). Subsequently, the specimens were mounted in metalized aluminum cylinders and covered with conductive material (gold) by sputtering in Denton Vacuum equipment, Desk V, and evaluated in a Jeol scanning electron microscope (SEM), JSM - 6610, equipped with EDS, Thermoscientific NSS Spectral Imaging. The generated images were digitally recorded, with variable potential difference of 2.5 to $5 \mathrm{Kv}$ and working focal length of $14-16 \mathrm{~mm}$.

\section{Results}

\subsection{In vitro dry matter digestibility}

As expected, it was observed that of the Tifton 85 of the genus Cynodon presents superior nutritional quality (Table 1). Consequentially, for the four inoculuDM evaluated, $U$. decumbens IVDMD was significantly lower (35.3 to $42.1 \%$ ), compared to that observed for Tifton 85 (51.6 to 60.2\%). Treatments with A. fumigatus and fungal mix promoted a significant increase in the IVDMD of $U$. decumbens (Table 2). For Tifton 85 hay the digestibility was higher using the A3 (A. fumigatus) treatment $(P<0.05)$.

After inclusion of the isolate AF69 and the mix containing both fungi was observed an increase in the U. decumbens digestibility by approximately $7 \%$. For Tifton 85 , the increase was observed up to $8.6 \%$ with the addition of this isolate.

Table 2 - In vitro digestibility of dry matter of Urochloa decumbens and Cynodon dactylons var Tifton 85 hays inoculated with Aspergillus spp. from the digestive tract of cattle.

\begin{tabular}{lcc}
\hline Inoculums & U. decumbens $(\%)$ & C. dactylons var Tifton 85 (\%) \\
\hline Control without fungi & $35.27 \mathrm{Bb}$ & $53.95 \mathrm{Ab}$ \\
AT13 - Inoculum with fungus AT13 & $35.98 \mathrm{Bb}$ & $51.64 \mathrm{Ac}$
\end{tabular}



AT69 - Inoculum with fungus AF69
$42.08 \mathrm{Ba}$
$60.18 \mathrm{Aa}$
MIX - Inoculum with Fungal Mix
$41.31 \mathrm{Ba}$
$55.57 \mathrm{Ab}$

Note: The differences in capital letters in the rows, for the forage types, and low letters in the columns, for the inoculuDM types, indicate different means by the Scott-Knott test at 5\% probability. Source: Authors.

\subsection{Degradation and fermentation by the semi-automatic gas production method}

The dry matter degradability was not influenced by the treatments $(P>0.05)$, as shown in the Table 3 . Synergistic effect of the two fungi isolates was not observed to Tifton 85 fermentation (Table 3 ). However, this effect was verified for the production of gas in the $U$. decumbens.

Despite the significant interaction between the type of fungal additive and time, the pressure produced by the fermentation (measured in psi) did not differ $(P>0.05)$ among the treatments evaluated within each time. This result occurred for both forages. Thus, the non-cumulative gas production was not influenced by the fungi addition, but was significant for the fermentation time ( $\mathrm{Y}$ Urochloa=0.22+0.01X, $\mathrm{R}^{2}=0.99 ; \mathrm{Y}$ Tifton=0.44+0.07X, $\left.\mathrm{R}^{2}=0.97\right)(P<0.05)$.

\subsection{Scanning electron microscopy analysis}

In the control, no microbial growth was observed, preserving the forage cell wall structure (Figure 1). In the Figure 2 and 3, the colonization of the fungus isolates was observed with 24 and 96 hours of incubation, under a smaller increase.

Development of both fungi isolates on the surface of plant fibers has been confirmed, showing capacity of these organisms to colonize and to degrade tropical forages such as $U$. decumbens. A distinct development profile was observed among the fungal species evaluated, with the highest mycelial mass produced by AT13 isolate (Figure 2). AF69, while producing less mycelium, there was more evenly distributed throughout the tested forage fragment (Figure 3).

Figure 1 - Fragment of Urochloa decumbens incubated in solution without addition of fungi under scanning microscopy voltage of $3.0 \mathrm{Kv} ; 25 \mathrm{x}$ 
Research, Society and Development, v. 10, n. 8, e56410817340, 2021

(CC BY 4.0) | ISSN 2525-3409 | DOI: http://dx.doi.org/10.33448/rsd-v10i8.17340

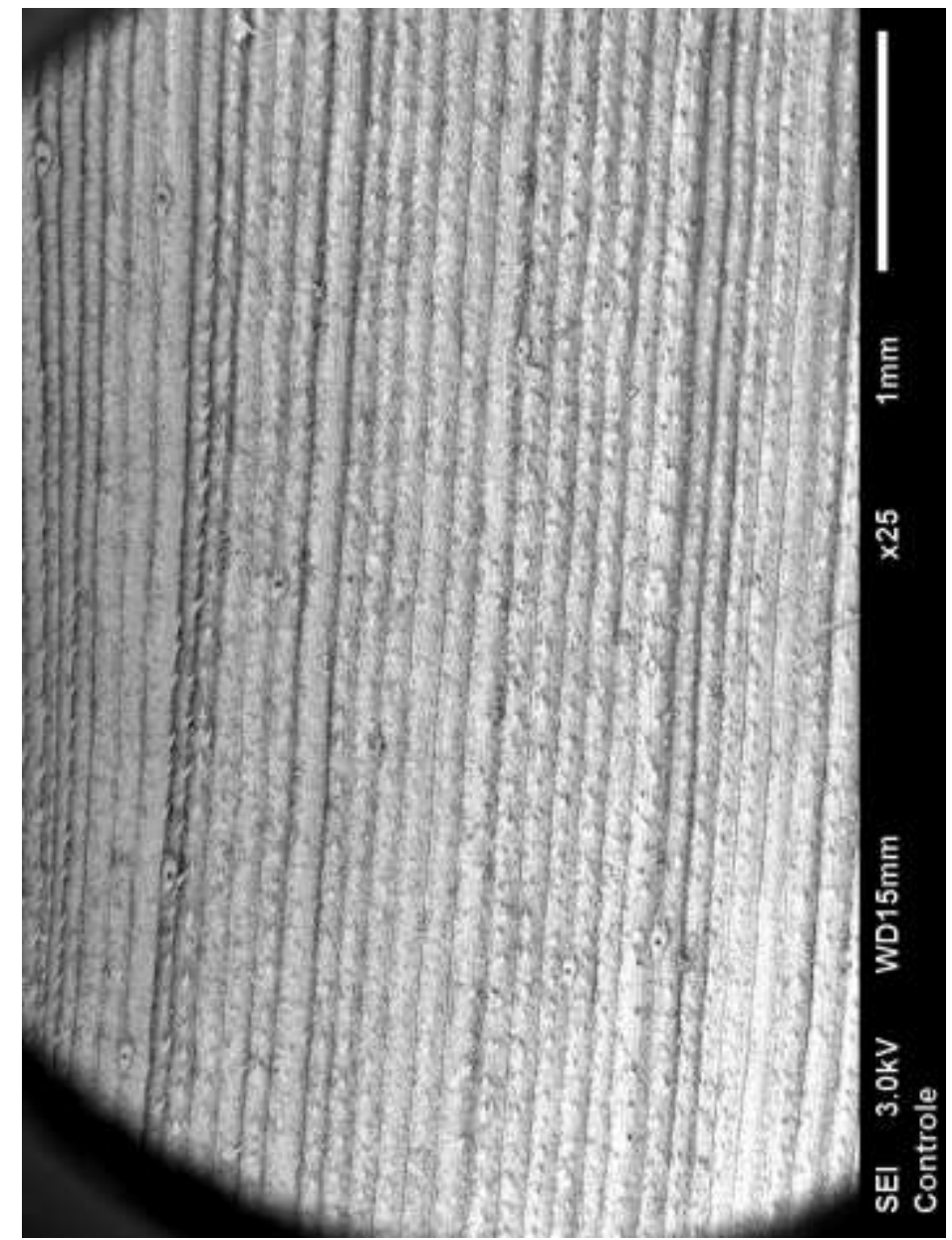

Source: Authors.

Figure 2 - Aspergillus terreus AT13 colonizing of Urochloa decumbens fragment after 24 (2a) and 96 (2b) hours of incubation under $3.0 \mathrm{Kv}$ scanning - strain microscopy; $25 \mathrm{x}$
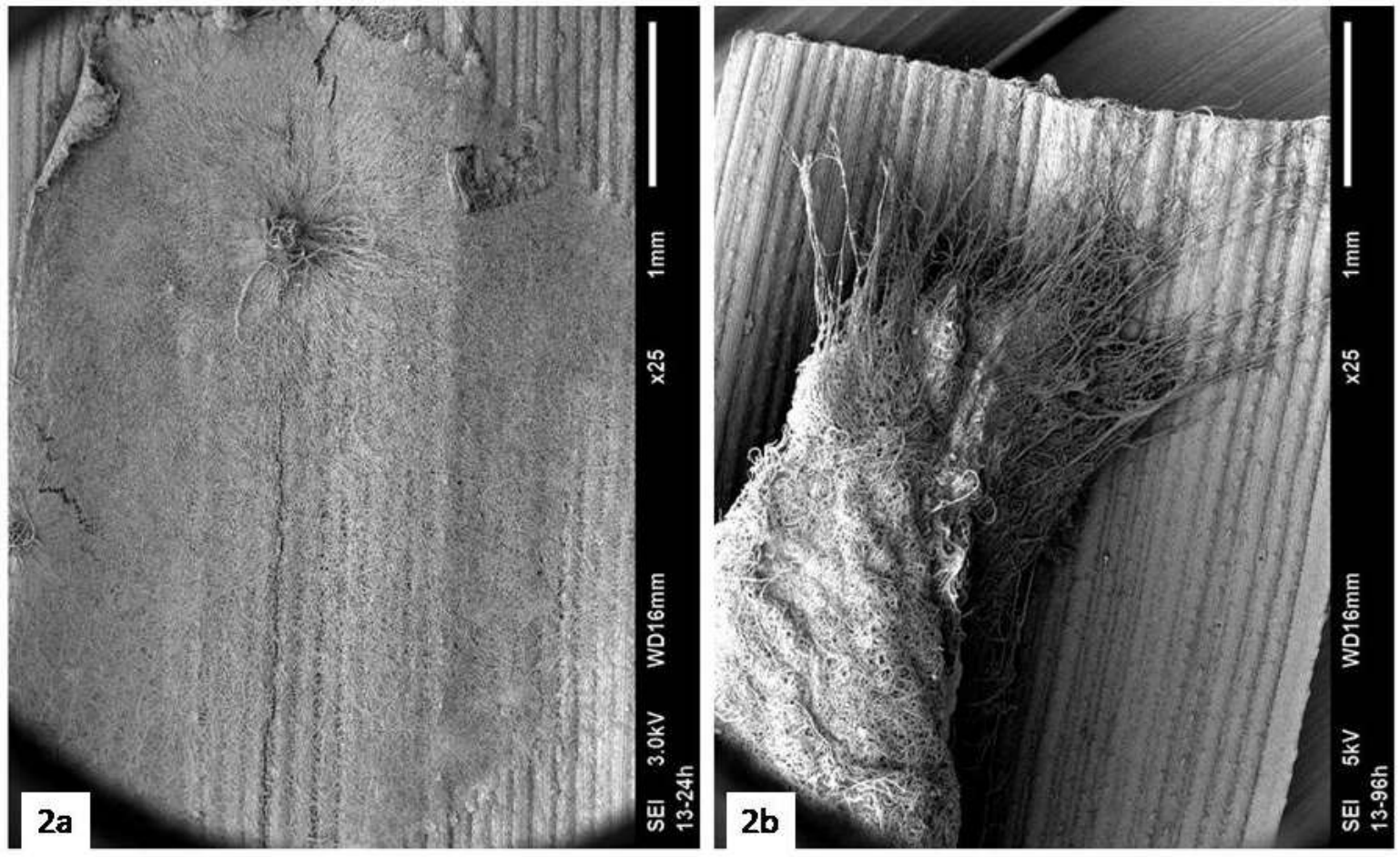

Source: Authors. 
Figure 3 - Aspergillus fumigatus AF69 colonizing of the Urochloa decumbens fragment after 24 (3a) and 96 (3b) hours of incubation under $3.0 \mathrm{kv}$ scanning-strain microscopy; $25 \mathrm{x}$
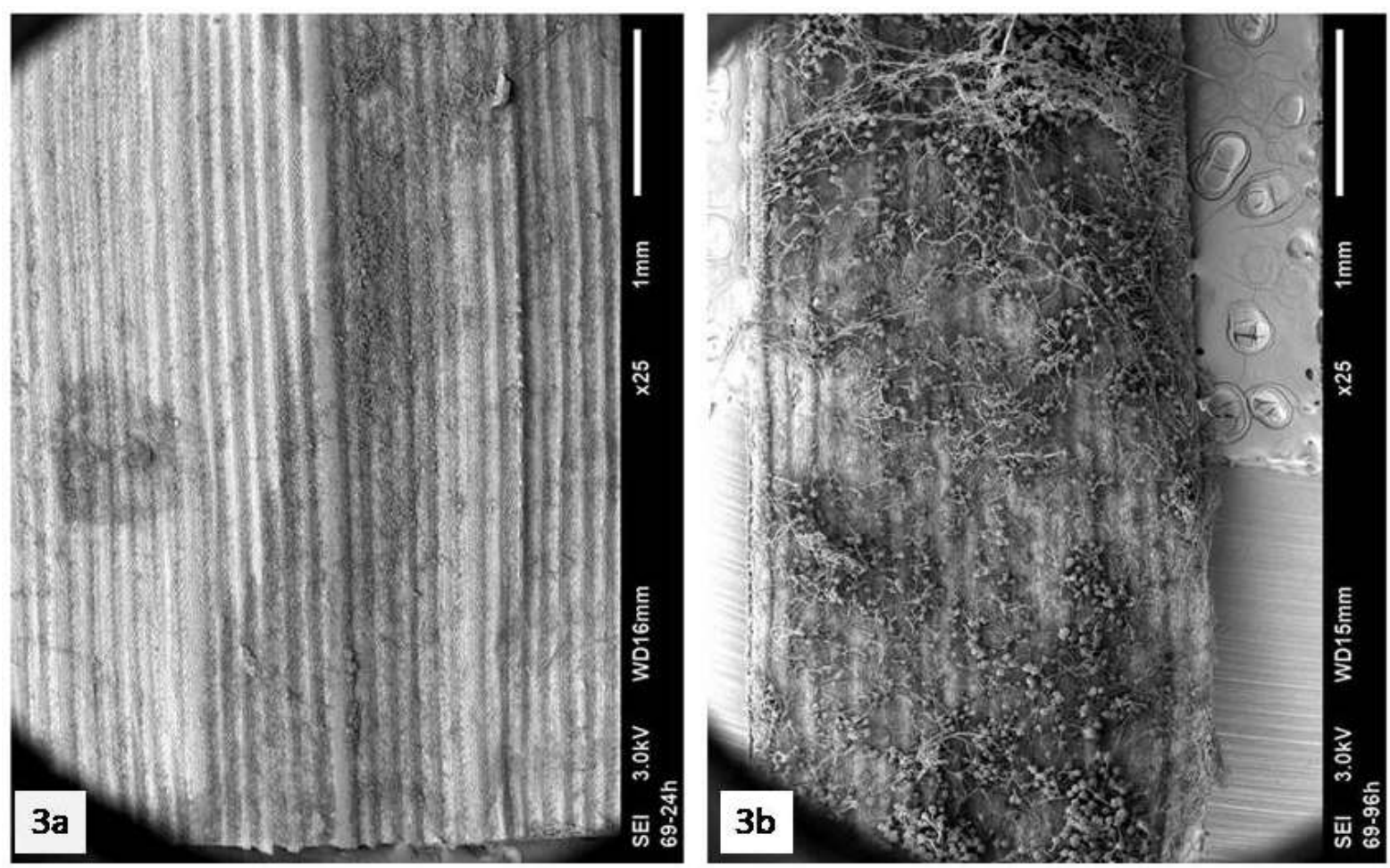

Source: Authors.

Table 3 - Dry matter degradability (\%) of Cynodon dactylons Tifton 85 and Urochloa decumens with and without addition of Aspergillus spp. from the bovine gastrointestinal tract.

\begin{tabular}{lcccccccc}
\hline \multicolumn{1}{c}{ Fungi/Time } & $6 \mathrm{~h}$ & $12 \mathrm{~h}$ & $24 \mathrm{~h}$ & $48 \mathrm{~h}$ & $96 \mathrm{~h}$ & Equation & $\mathrm{R}^{2}$ & $\mathrm{CV}$ \\
\hline \multicolumn{2}{l}{ Cynodon dactylons Tifton 85} & & & & & & & \\
Control & 16.35 & 18.68 & 23.14 & 31.19 & 36.87 & $\mathrm{Y}=13.25+0.48 \mathrm{X}^{* *}$ & 0.99 & 9.38 \\
AT13 & 16.48 & 20.21 & 23.05 & 35.95 & 41.93 & $\mathrm{Y}=11.54+1.24 \mathrm{X}^{* *}$ & 0.99 & 8.65 \\
AF69 & 15.50 & 19.29 & 22.99 & 32.89 & 41.27 & $\mathrm{Y}=11.23+1.02 \mathrm{X}^{* *}$ & 0.99 & 5.22 \\
Mix & 19.72 & 20.08 & 20.54 & 31.97 & 37.06 & $\mathrm{Y}=16.07+0.33 \mathrm{X}^{* *}$ & 0.91 & 15.5 \\
Urochloa decumens & & & & & & & & \\
Control & 6.51 & 6.58 & 9.60 & 19.43 & 27.24 & $\mathrm{Y}=2.78+0.38 \mathrm{X}^{* *}$ & 0.98 & 18.13 \\
AT13 & 4.89 & 7.54 & 8.70 & 22.22 & 26.57 & $\mathrm{Y}=1.39+1.46 \mathrm{X}^{* *}$ & 0.99 & 13.88 \\
AF69 & 4.66 & 5.93 & 9.28 & 20.79 & 26.59 & $\mathrm{Y}=3.42+0.21 \mathrm{X}^{* *}$ & 0.99 & 13.56 \\
Mix & 5.54 & 5.90 & 8.10 & 19.93 & 26.88 & $\mathrm{Y}=5.46+0.006 \mathrm{X}^{* *}$ & 0.99 & 9.72 \\
\hline
\end{tabular}

Note: Comparisons in the column by the Scott-Knott test did not differ at the $5 \%$ level of significance. ** Significant equation at $1 \%$ probability. $\mathrm{CV}=$ coefficient of variation $(\%)$. Source: Authors.

\section{Discussion}

The increase of the $U$. decumbens digestibility with the AF69 inclusion could demonstrate the potential of this fungus as a microbial additive in the diet of ruminants fed with tropical forages In a previous study, the analysis of AT13 and AF69 did not show this isolates as micotoxin produces and they were resistant to different proportions of ruminal fatty acids. 
Additionally, these fungi presented viability on autochthonous microbiota, showing physiological characteristics to be used with microbial additives or probiotic (Abrão et al. 2018).

In this study, tested fungal additives did not influence the DM degradability, which could have been influenced by the variability of the results obtained in semi-automatic gas production technique. However, the degradability of both forages linearly increased with the fermentation time, indicating that the 96-hour period was more suitable to achieve better rates, allowing better colonization and performance of fibrolytic ruminal microbiota. Future studies should elucidate this effect, as well as the influence of fungal additives on the digestibility of FDN and, crude protein, among others.

As expected, $U$. decumbens showed lower digestibility and degradability of DM than $C$. nlenfuensis and were justified by their differences in nutritional compositions. The U. decumbens was collected at the end of the dry season and it presented low nutritional value and high lignification index of the vegetal tissues. Differently, Cynodon sp. presented superior nutritional quality because it was produced in haymaking process, and was collected when presented there was good nutritional characteristics, being removed only the moisture of the food.

The quantity and quality of pastures are drastically reduced during dry periods, in semiarid regions. The forage digestibility is reduced by the physiological lignification process in plant cell wall (Moore and Jung 2001). Fungi produce lignocellulolytic enzymes and contribute synergistically to the decay of lignocellulosic residues in nature (Dashtban et al. 2010). When lignin complex is removed, cellulose and other carbohydrates may be released for ruminal microbiota actuation (Kamra 2005).

In previous study, AT13 and AF69 isolates presented intense production of phenoloxidases, important lignindegrading enzymes (Abrão et al. 2017), suggesting their potential to degrade lignified forage during the dry season. Additionally, these fungi showed expressive production of avicelases that were higher at $48 \mathrm{~h}$ than at $24 \mathrm{~h}$ of incubation, probably due to an adjustment period of fungal growth in vegetal fiber (Abrão et al. 2017). Avicelases are import to bioconversion of agricultural wastes to useful products, catalyzing most of the bond-cleavages during saccharification of microcrystalline cellulose (Liu et al. 2011).

Similarly to the observed in this study, anaerobic ruminal fungi promoted major importance for tropical forage digestion and degradation lignified fibers (Lee et al. 2000, Paul et al. 2004) than forages with better quality. In another study, the in vitro analyzes of fiber digestibility and ruminal fermentation revealed that the addition of rumen anaerobic fungal cultures significantly increased acetate production, in vitro dry matter digestibility and microbial biomass synthesis. The inclusion of Orpinomyces spp. showed better plant fiber degrader than Anaeromyces sp. (Sirohi et al. 2012).

Scanning microscopy reinforced the results reported in the other experiments of this study, validating the ability of fungal isolates to colonize tropical forage fiber, demonstrating a distinct growth profile among fungi, which could confirm the higher probiotic capacity of isolate AF69 on the digestibility of $U$. decumbens. In another study, Curvelo et al. (2010) also demonstrated ability of the fungi Ramularia areola on the development in plant samples, and points to sporulation via stomata in leaf veins because, in direct contact with the xylem vessels.

\section{Conclusion}

In this study, the addition of the isolate AF69 (Aspergillus fuminatus), from Nelore calf, promotes a significant increase of the IVDMD for $U$. decumbens, pointing promising potential for the elaboration of probiotic or microbial additive for cattle raised in pastures containing this forage. The AF69 (A. fumigatus) and AT13 (A. terreus) isolates are able to colonize the surface of the vegetal fiber, which could favor the digestibility of the lignified vegetal fiber and use by other groups of ruminal microorganisms. Future studies should elucidate the best formulations and strategies to use these fungi in diets of cattle fed on lignified forages 


\section{Acknowledgments}

This study was funded by Coordination for the Improvement of Higher Education Personnel (CAPES), National Council for Scientific and Technological Development (CNPq 308204 / 2015-8 and CNPq- 310898 / 2018-8), Research Support Foundation of the State of Minas Gerias (FAPEMIG , PPM-00393-17). Pro Reitoeria of Research of the Universidade Federal de Mina Gerais (UFMG), and Instituto Federal Goiano of Brazil (IFG), Campus Ceres.

\section{Ethical statement}

This study is original and unpublished and has not been submitted elsewhere at the present time. All the procedures performed in this experiment were approved by the Animal Experimentation Ethics Committee of the Federal University of Minas Gerais under registration CETEA 128/2013.

\section{References}

Abrao, F. O., Duarte, E. R., Pessoa, M. S., Santos, V. L., Freitas Júnior, L. F, Barros K. O., Hughes A. F. S., Silva, T. D. \& Rodriguez N. M. (2017). Notable fibrolytic enzyme production by Aspergillus spp. isolates from the gastrointestinal tract of beef cattle fed in lignied pastures. PLoS ONE, 128, 1-9. https://doi.org/10.1371/journal.pone.0183628

Abrão, F. O., Duarte, E. R., Rosa, C. A., Freitas, C. E. S., Vieira, E. A. \& Huhges, A. F. S. (2014). Characterization of fungi from ruminal fluid of beef cattle with different ages and raised in tropical lignified pastures. Current Microbiology. 695, 649-659. https://doi: 10.1007/s00284-014-0633-5

Abrão, F. O., Duarte, E. R., Pessoa, M. S., Santos, L. V. \& Rodrigues, N. M. (2018). Mycotoxicological safety and viability of Aspergillus spp.with probiotic potential from the bovine digestive tract. Arquivo Brasileiro de Medicina Veterinária e Zootecnia. 70, 833-1839. https://doi.org/10.1590/1678-4162-9853

Almeida P. N. M., Freitas C. E. S., Abrão F.O., Ribeiro I. C. O., Vieira E. A, Geraseev L. C. \& Duarte E. R. (2014). Atividade celulolítica de fungos aerobios isolados do rúmen de bovinos leiteiros alimentados com forragens tropicais. Revista Caatinga, 274, 202-207.

Ankom, Technology (2014). Method 3: In vitro true digestibility using the DAISYII Incubator. (http://www.ankom.com/media/documents/ IVDMD_0805_D200.pdf.)

Chiou, P. W. S., Chen, C. R., Bi \& Yu, B. (2002). Effects of Aspergillus oryzae fermentation extract on performance of lactating cows in the summer and winter in Taiwan. Asian-Austral. Journal Animal Science, 15:382-389. https://doi.org/10.5713/ajas.2002.382

Curvelo, C. R. S., Rodrigues, R. A., Berger, P. G. \& Rezende D. C. (2010). Microscopia eletrônica de varredura do processo infeccioso de Ramularia areola em folhas de algodoeiro. Tropical Plant Pathology, 352,108-113. https://doi.org/10.1590/S1982-56762010000200006

Dashtban, M., Schraft, H., Syed, T. A. \& Qin, W. (2010). Fungal biodegradation and enzymatic modification of lignin. International Journal of Biochemistry and Molecular Biology.1:36-50. https://doi.org/10.1590/S1982-56762010000200006

Facchini, F. D. A., Vici, A. C., Reis, V. R. A., Jorge, J. A., Terenzi, H. F., Reis, R. A. \& Polizeli, M.L.T.M. (2011). Production of fibrolytic enzymes by Aspergillus japonicas $\mathrm{C} 03$ using agro-industrial residues with potential application as additives in animal feed. Bioprocess and BiosysteDM Engineeringi, 34,347-355. . https://doi:10.1007/s00449-010-0477-8

Hartinger, T. \& Zebeli, Q. (2021). The Present Role and New Potentials of Anaerobic Fungi in Ruminant Nutritionm. Journal Fungi, 3, 200. https://doi.org/10.3390/jof7030200

Holden, L. A. (1999). Comparison of methods of in vitro dry matter digestibility for ten feeds. Journal Dairy Science, 828,1791-1794. https://doi: $10.3168 /$ jds.S0022-0302(99)75409-3.

Kamra, D.N. (2005). Rumen Microbial Ecosystem. Current Sience 89,125-135. https://doi:10.15406/BIJ.2017.01.00016

Lee, S. S., Ha, J. K. \& Cheng, K. J. (2000). Influence of an anaerobic fungal culture administration on in vivo ruminal fermentation and nutrient digestion Animal Feed Science and Technology, 88,201-217. https://doi10.1016/S0377-8401(00)00216-9

Liu, Y. S., Baker, J. O., Zeng, Y., Himmel, M. E., Haas, T., \& Ding, S. Y. (2011).Cellobiohydrolase hydrolyzes crystalline cellulose on hydrophobic faces. Journal Biological Chemistry 286(13), 11195-11201. https://doi.org/ 10.1074/jbc.M110.216556.

Liu, K., Zhang, Y., Xu, Q., Zheng, N., Zhao, S., Huang, G \& Wang, J. (2020). Ruminal microbiota-host interaction and its effect on nutrient metabolism. Animal Nutrition, 7, 49-55. https://doi.org/10.1016/j.aninu.2020.12.001

Moore, K. J. \& Jung, H. J. G. (2001). Lignin and fiber digestion. Journal of Range Management, 54, 420-430. https://doi:10.2307/4003113

Paul, S. S., Kamra, D. N., Sastry, V. R. B., Sahu, N. P. \& Agarwal, N. (2004). Effect of anaerobic fungi on in vitro feed digestion by mixed rumen microflora of buffalo. Reproduction, Nutrition Development. 44,313-319. https//doi.10.1051/rnd:2004036. 
Research, Society and Development, v. 10, n. 8, e56410817340, 2021

(CC BY 4.0) | ISSN 2525-3409 | DOI: http://dx.doi.org/10.33448/rsd-v10i8.17340

Russell, J. B. \& Rychlik, J. L. (2001). Factors that alter rumen microbial ecology. Science 11,1119-1122. . https//doi.10.1126/science.1058830.

Sobhy, M. A., Sallam, Mina, L. R., Abdelmalek, A. E., Kholif Soliman, M. Z., Mohamed, H. A., Hassan, S. Z., Marwa, F.A.A., Osama H.M \& Olurotimi, A. O. (2020). The effect of Saccharomyces cerevisiae live cells and Aspergillus oryzae fermentation extract on the lactational performance of dairy cows. Animal Biotechnology, 31, 6, 491-497. https//doi.10.1080/10495398.2019.1625783

Sirohi, S. K., Choudhury, P. K., Dagar, S. S., Puniy, A. K.\& Singh D. (2012). Isolation, characterization and fibre degradation potential of anaerobic rumen fungi from cattle. Annals Microbiology. 1, 1-10. https://doi.org/10.1007/s13213-012-0577-6

Tilley, J. M. A. \& Terry R. A. (1963). A two-stage technique for in vitro digestion of forage crops. Journal of the British Grassland Society. 18, 104-111. https://doi:10.1111/j.1365-2494.1963.tb00335.x

Yang, W. Z., Beauchemin, K. A. \& Rode, L. M. (2000). A comparison of methods of adding fibrolytic enzymes to lactating cow diets. Journal Dairy Sciense. 83, 2512-2520. https://doi.org/10.3168/jds.S0022-0302(00)75143-5

Zilio, E. M. C, Del Valle, T. A., Ghizzi, L. G., Takiya, C. S., Dias, M. S.,S, Nunes, A., Silva, G .G. \& Rennó F.P. (2019). Effects of exogenous fibrolytic and amylolytic enzymes on ruminal fermentation and performance of mid-lactation dairy cows. Journal Dairy Sciense. 1025, 4179-4189. :https://doi.org/10.3168/jds.2018-14949 